\title{
Analisis Faktor Praktik Pemberian Makanan dan Sosial Ekonomi dengan Anemia Defisiensi Gizi Besi pada Balita di Ruang Anak Rumah Sakit Umum Tgk Chik Ditiro Kabupaten Pidie
}

\author{
Factor Analysis of Food and Socio-Economic Giving Practices with Iron \\ Nutrition Deficiency Anemia in Toddlers in The Child's Room General \\ Hospital Tgk Chik Ditiro, Pidie District \\ Nuzulul Rahmi ${ }^{* 1}$, Azimar ${ }^{2}$, Fauziah Andika ${ }^{3}$ \\ ${ }^{1}$ Program Studi Diploma III Kebidanan, Fakultas Ilmu Kesehatan, Universitas Ubudiyah Indonesia \\ ${ }^{2}$ Bidan Rumah Sakit Umum Tgk Chik Ditiro Kabupaten Pidie \\ ${ }^{3}$ Program Studi S-1 Kesehatan Masyarakat, Fakultas Ilmu Kesehatan Universitas Ubudiyah Indonesia \\ *Korespondensi Penulis : nuzulul_r@uui.ac.id
}

\begin{abstract}
Abstrak
Upaya penanggulangan anemia gizi masih difokuskan pada sasaran ibu hamil, sedangkan kelompok lainnya seperti bayi, anak balita, anak sekolah dan buruh berpenghasilan rendah belum ditangani. Padahal dampak negatif yang ditumbuhkan anemia gizi pada anak balita sangatlah serius, karena mereka sedang dalam tumbuh kembang yang cepat, yang nantinya akan berpengaruh terhadap perkembangan kecerdasannya. Mengingat mereka adalah penentu dari tinggi rendahnya kualitas pemuda dan bangsa kelak. Penganganan sedini mungkin sangatlah berarti bagi kelangsungan pembangunan. Jenis penelitian adalah penelitian analitik dengan rancangan cross sectional Penelitian dilakukan di poli kebidanan Rumah Sakit Umum Tgk Chik Ditiro Sigli pada tanggal 17 Oktober-13 November 2017. Teknik pengambilan sampel secara accidental sampling terhadap $57 \mathrm{ibu}$ balita. Data diperoleh melalui penyebaran kuesioner. Pengolahan data menggunakan uji statistic (chi square test) dengan tingkat kepercayaan $95 \%(\mathrm{p} \leq 0,05)$. Hasil penelitian menunjukan bahwa dari segi kejadian anemia mayoritas balita mengalami anemia gizi besi ringan yaitu berjumlah 21 orang $(36,8)$. Dari segi sosial ekonomi mayoritas ibu balita memiliki sosial ekonomi dalam kategori rendah yaitu berjumlah 36 orang $(63,2 \%)$. Dari segi praktek pemberian makanan oleh ibu balita mayoritas berada dalam kategori kurang baik yaitu berjumlah 37 orang $(64,9 \%)$. Hasil bivariat menunjukkan faktor sosial ekonomi berhubungan dengan kejadian AGB pada balita ( $P$-value $0,015)$ dan faktor praktek pemberian makanan berhubungan dengan kejadian AGB pada balita (P-value 0,002).
\end{abstract}

Kata kunci : Anemia, Defisiensi gizi besi, Sosial ekonomi dan Praktik Pemberian makanan

\begin{abstract}
Efforts to overcome nutritional anemia are still focused on the target of pregnant women, while other groups such as infants, toddlers, school children and low income workers have not been addressed. Even though the negative impact of nutrition anemia in children under five is very serious, because they are in rapid growth and development, which will later affect the development of intelligence. Given that they are the determinant of the high and low
\end{abstract}


quality of the youth and the nation in the future. Handling as early as possible is very meaningful for the continuity of development. This type of research is analytical research with cross sectional design. The study was conducted at the midwifery clinic in Tgk Chik General Hospital Ditiro Sigli on October 17-November 13, 2017. The sampling technique was accidental sampling of 57 mothers of children under five. Data obtained through questionnaires. Processing data using a statistical test (chi square test) with a confidence level of 95\% ( $p 5$ 0.05). The results showed that in terms of the incidence of anemia the majority of children under five had mild iron nutrition anemia, amounting to 21 people (36.8). In terms of socio-economic the majority of mothers of children under five have socioeconomic in the low category, amounting to 36 people (63.2\%). In terms of the practice of feeding by mothers of children under five the majority are in the poor category, amounting to 37 people (64.9\%). Bivariate results showed socioeconomic factors related to the incidence of $A G B$ in children under five (P-value 0.015) and feeding practices related to the incidence of $A G B$ in infants ( $P$-value 0.002).

Keywords : Anemia, iron nutrition deficiency, socioeconomic and food delivery practices.

\section{PENDAHULUAN}

Anemia merupakan suatu keadaan ketika jumlah sel darah merah atau konsentrasi pengangkut oksigen dalam darah $(\mathrm{Hb})$ tidak mencukupi untuk kebutuhan fisiologis tubuh. Cut-off points anemia berbeda-beda antar kelompok umur, maupun golongan individu. Kelompok umur atau golongan individu tertentu dianggap lebih rentan mengalami anemia dibandingkan kelompok lainnya. Rujukan cut-off point anemia balita 12-59 bulan adalah kadar Hb dibawah 11,0 g/dL (Kemenkes RI, 2013).

Berdasarkan Kepmenkes RI (2016) Anemia Gizi Besi (AGB) diderita oleh 8,1 juta anak balita. Sementara Kemenkes RI (2017) menguraikan berdasarkan laporan riset kesehatan dasar menunjukkan proporsi penduduk umur $\geq 1$ tahun dengan keadaan anemia mencapai $21,7 \%$ secara nasional dengan proporsi $20,6 \%$ di perkotaan dan 22,8\% di pedesaan serta 18,4\% laki-laki dan 23,9\% perempuan. Pengelompokan umur, didapatkan bahwa anemia pada balita 12-59 bulan cukup tinggi, yaitu 28,1\%.

Rahmawati (2015) menjelaskan bahwa dampak negatif yang ditimbulkan anemia gizi pada anak balita sangat serius, secara perlahan-lahan akan menurunkan daya tahan tubuh, menghambat pertumbuhan dan perkembangan, infeksi, dan berpengaruh pada kecerdasan dan perkembangan otak maupun fisik anak yang mengakibatkan prestasi sekolah yang buruk.

Menurut Wahyuni (2014) penyebab utama anemia gizi adalah konsumsi zat besi yang tidak cukup dan absorbsi zat besi yang rendah dan pola makan yang sebagian besar terdiri dari nasi dan menu yang kurang beraneka ragam. Selain itu infestasi cacing tambang memperberat 
keadaan anemia yang diderita pada daerah-daerah tertentu terutama daerah pedesaan. Anemia gizi juga dipengaruhi oleh faktor-faktor lain seperti sosial ekonomi, pendidikan, status gizi dan pola makan, fasilitas kesehatan, pertumbuhan, daya tahan tubuh dan infeksi. Faktorfaktor tersebut saling berkaitan.

Studi pendahuluan yang dilakukan di Rumah Sakit Umum Daerah Tgk Chik Ditiro Sigli diketahui bahwa tahun 2014 balita yang mengalami anemia sebanyak 213 orang (15,3\%) dari 1384 balita, tahun 2015 sebanyak 205 orang (11,5\%) dari 1780 balita dan tahun 2016 sebanyak 275 orang $(14,6 \%)$ dari 1871 balita, sementara data pada tahun 2017 dari bulan Januari sampai dengan Juli diketahui balita yang anemia sebanyak 143 orang (8,7\%) dari 1640 balita yang dirawat. Sedangkan data terakhir pada bulan Agustus diketahui balita yang anemia sebanyak 23 orang $(17,6 \%)$ dari 130 balita yang dirawat. Dari data tersebut terlihat peningkatan kasus anemia yang diderita oleh balita. Berdasarkan latar belakang tersebut maka penulis tertarik melakukan penelitian untuk mengetahui faktor-faktor yang berhubungan dengan anemia defisiensi gizi besi pada balita.

\section{METODE PENELITIAN}

Jenis penelitian adalah penelitian analitik dengan rancangan cross sectional Penelitian dilakukan di poli kebidanan Rumah Sakit Umum Tgk Chik Ditiro Sigli pada tanggal 17 Oktober-13 November 2018. Teknik pengambilan sampel secara accidental sampling terhadap $57 \mathrm{ibu}$ balita. Data diperoleh melalui penyebaran kuesioner. Pengolahan data menggunakan uji statistic (chi square test) dengan tingkat kepercayaan 95\% ( $\leq \leq 0,05)$.

\section{HASIL DAN PEMBAHASAN}

Tabel 1. Distribusi Frekuensi Kejadian Anemia Defisiensi Gizi Besi pada Balita di Ruang Anak Rumah Sakit Umum Daerah Tgk Chik Ditiro Kabupaten Pidie

\begin{tabular}{lccc}
\hline $\begin{array}{l}\text { Kejadian Anemia Gizi Besi } \\
\text { Pada Balita }\end{array}$ & Frekuensi (n) & Persentase (\%) \\
\hline Ringan & 24 & 42,1 \\
Sedang & 19 & 33,3 \\
Berat & Jumlah & 14 & 24,6 \\
\hline \multicolumn{2}{c}{} & $\mathbf{5 7}$ & $\mathbf{1 0 0}$ \\
\hline
\end{tabular}


Dari tabel 1 menunjukkan bahwa mayoritas balita mengalami anemia gizi besi ringan yaitu berjumlah 24 orang $(42,1)$. Sedangkan anemia sedang berjumlah 19 orang $(33,3 \%)$ dan yang mengalami kejadian anemia berat adalah 14 orang $(24,6 \%)$.

Tabel 2. Distribusi Frekuensi Sosial Ekonomi Ibu Balita di Ruang Anak Rumah Sakit Umum Daerah Tgk Chik Ditiro Kabupaten Pidie

\begin{tabular}{lcc}
\hline \multicolumn{1}{c}{ Sosial Ekonomi } & Frekuensi (n) & Persentase (\%) \\
\hline Rendah & 36 & 63,2 \\
Tinggi & 21 & 36,8 \\
\hline \multicolumn{1}{c}{ Jumlah } & $\mathbf{5 7}$ & $\mathbf{1 0 0}$ \\
\hline
\end{tabular}

Tabel 2 menunjukkan bahwa mayoritas ibu balita memiliki sosial ekonomi dalam kategori rendah yaitu berjumlah 36 orang $(63,2 \%)$. Sedangkan yang berada pada kategori sosial ekonomi tinggi berjumlah 21 orang $(36,8 \%)$.

Tabel 3. Distribusi Frekuensi Sosial Ekonomi Ibu Balita di Ruang Anak Rumah Sakit Umum Daerah Tgk Chik Ditiro Kabupaten Pidie

\begin{tabular}{|c|c|c|}
\hline $\begin{array}{c}\text { Praktek Pemberian } \\
\text { Makanan }\end{array}$ & Frekuensi (n) & Persentase (\%) \\
\hline Kurang & 37 & 64,9 \\
\hline Baik & 20 & 35,1 \\
\hline Jumlah & 57 & 100 \\
\hline
\end{tabular}

Tabel 3 menunjukkan bahwa praktek pemberian makanan oleh ibu balita mayoritas berada dalam kategori kurang yaitu berjumlah 37 orang (64,9\%). Sedangkan yang berada pada kategori baik berjumlah 20 orang $(35,1 \%)$.

Tabel 4. Hubungan Sosial Ekonomi Dengan Kejadian Anemia Gizi Besi pada Balita di Ruang Anak Rumah Sakit Umum Daerah Tgk Chik Ditiro Kabupaten Pidie

\begin{tabular}{|c|c|c|c|c|c|c|c|c|c|}
\hline \multirow{3}{*}{$\begin{array}{c}\text { Sosial } \\
\text { Ekonomi }\end{array}$} & \multicolumn{6}{|c|}{ Kejadian AGB pada Balita } & \multirow{2}{*}{\multicolumn{2}{|c|}{ Total }} & \multirow{2}{*}{ P value } \\
\hline & \multicolumn{2}{|c|}{ Ringan } & \multicolumn{2}{|c|}{ Sedang } & \multicolumn{2}{|c|}{ Berat } & & & \\
\hline & $\mathbf{n}$ & $\%$ & n & $\%$ & $\mathbf{n}$ & $\%$ & $\mathbf{n}$ & $\%$ & \multirow{4}{*}{0,023} \\
\hline Rendah & 14 & 38,9 & 9 & 25,0 & 13 & 36,1 & 36 & 100 & \\
\hline Tinggi & 10 & 47,6 & 10 & 47,6 & 1 & 4,8 & 21 & 100 & \\
\hline Jumlah & 24 & 42,1 & 19 & 33,3 & 14 & 24,6 & 57 & 100 & \\
\hline
\end{tabular}


Tabel 4 menunjukkan bahwa ibu balita yang merupakan sosial ekonomi rendah sebagian besar memiliki balita yang mengalami AGB ringan yaitu sebanyak 14 (38,9\%). Sedangkan ibu balita dengan sosial ekonomi tinggi sebagian besar memiliki balita yang mengalami AGB ringan yaitu berjumlah 10 orang (47,6\%). Berdasarkan perhitungan uji statistik dengan Chi Square diperoleh P-value 0,023 nilai tersebut lebih kecil dari $\alpha=0,05$ sehingga memperlihatkan ada hubungan antara sosial ekonomi dengan kejadian AGB pada balita di ruang anak Rumah Sakit Umum Tgk Chik Ditiro Kabupaten Pidie.

Tabel 5. Hubungan Praktek Pemberian Makanan dengan Kejadian Anemia Gizi Besi pada Balita di Ruang Anak Rumah Sakit Umum Daerah Tgk Chik Ditiro Kabupaten Pidie

\begin{tabular}{|c|c|c|c|c|c|c|c|c|c|}
\hline \multirow{3}{*}{$\begin{array}{l}\text { Praktek } \\
\text { Pemberian } \\
\text { Makanan }\end{array}$} & \multicolumn{6}{|c|}{$\begin{array}{c}\text { Kejadian AGB } \\
\text { Pada Balita }\end{array}$} & \multirow{2}{*}{\multicolumn{2}{|c|}{ Total }} & \multirow[t]{2}{*}{$P$ value } \\
\hline & \multicolumn{2}{|c|}{ Ringan } & \multicolumn{2}{|c|}{ Sedang } & \multicolumn{2}{|c|}{ Berat } & & & \\
\hline & $\mathbf{n}$ & $\%$ & $\mathbf{n}$ & $\%$ & $\mathbf{n}$ & $\%$ & $\mathbf{n}$ & $\%$ & \\
\hline Kurang & 12 & 32,4 & 11 & 29,7 & 14 & 37,8 & 37 & 100 & \\
\hline Baik & 12 & 60,0 & 8 & 40,0 & 0 & 0 & 20 & 100 & 0,006 \\
\hline Jumlah & 24 & 42,1 & 19 & 33,3 & 14 & 24,6 & 57 & 100 & \\
\hline
\end{tabular}

Tabel 5 menunjukkan bahwa ibu balita dengan praktek pemberian makanan yang kurang sebagian besar memiliki balita yang mengalami AGB berat yaitu sebanyak 14 $(37,8 \%)$. Sedangkan ibu balita dengan praktek pemberian makanan yang baik sebagian besar memiliki balita yang mengalami AGB ringan yaitu berjumlah 12 orang (60,0\%). Berdasarkan perhitungan uji statistik dengan Chi Square diperoleh P-value 0,006 nilai tersebut lebih kecil dari $\alpha=0,05$ sehingga memperlihatkan ada hubungan antara praktek pemberian makanan dengan kejadian AGB pada balita di ruang anak Rumah Sakit Umum Tgk Chik Ditiro Kabupaten Pidie.

\section{Pembahasan}

1. Hubungan Sosial Ekonomi dengan Kejadian Anemia Gizi Besi pada Balita di Ruang Anak Rumah Sakit Umum Tgk Chik Ditiro Kabupaten Pidie

Kondisi sosial ekonomi adalah suatu kedudukan yang diatur secara sosial dan menempatkan seseorang pada posisi tertentu dalam masyarakat, pemberian posisi itu disertai pula dengan seperangkat hak dan kewajiban yang harus dimainkan oleh orang yang membawa status tersebut. status sosial ekonomi mempunyai makna suatu keadaan yang 
menunjukan pada kemampuan finansial keluarga dan perlengkapan material yang dimiliki (Komala Sari, 2014). Menurut Pergub Aceh (2016) Upah Minimum Provinsi (UMP) Aceh Tahun 2017 ditetapkan sebesar Rp 2.500.000,- (dua juta lima ratus ribu rupiah).

Hasil penelitian menunjukkan bahwa ibu balita yang merupakan sosial ekonomi rendah sebagian besar memiliki balita yang mengalami AGB ringan yaitu sebanyak 14 $(38,9 \%)$. Sedangkan ibu balita dengan sosial ekonomi tinggi sebagian besar memiliki balita yang mengalami AGB ringan yaitu berjumlah 10 orang (47,6\%). Berdasarkan perhitungan uji statistik dengan Chi Square diperoleh $P$-value 0,023 nilai tersebut lebih kecil dari $\alpha=0,05$ sehingga memperlihatkan ada hubungan antara sosial ekonomi dengan kejadian AGB pada balita di ruang anak Rumah Sakit Umum Tgk Chik Ditiro Kabupaten Pidie.

Hasil penelitian ini sejalan dengan teori Soetjiningsih (2013) yang menjelaskan bahwa status sosial ekonomi adalah kedudukan atau posisi seseorang dalam masyarakat, status sosial ekonomi adalah gambaran tentang keadaan seseorang atau suatu masyarakat yang ditinjau dari segi sosial ekonomi, gambaran itu seperti tingkat pendidikan, pendapatan dan sebagainya. Status ekonomi kemungkinan besar merupakan pembentuk gaya hidup keluarga. Pendapatan keluarga memadai akan menunjang tumbuh kembang anak. Karena orang tua dapat menyediakan semua kebutuhan anak baik primer maupun skunder.

Jenis dan jumlah makanan yang dimakan oleh seseorang yang menjadi masukan sumber zat gizi bagi tubuh ditentukan pula oleh berbagai faktor, baik faktor sosial, budaya, kebiasaan dan kesukaan, pengetahuan dan perilaku, tingkat pendidikan maupun faktor ekonomi (Rahmawati, 2015).

Menurut Rahmawati (2015) Pekerjaan sebagai ibu rumah tangga memungkinkan pengalokasian waktu ibu untuk memperhatikan konsumsi dan kesehatan diri sendiri maupun keluarga menjadi lebih besar. Status dan jenis pekerjaan ibu mempengaruhi ketersediaan waktu ibu untuk mengelola pangan. hal ini cenderung untuk menjadi determinan keragaman konsumsi pangan di rumah tangga.

Menurut asumsi peneliti bahwa tingkat social ekonomi suatu keluarga mempengaruhi kejadian AGB dikarenakan pendapatan keluarga tersebut. Apabila pendapatan rendah, maka keluarga tidak sanggup menyediakan makanan dengan gizi seimbang untuk dikonsumsi oleh anggota keluarganya, sehingga besar kemungkinan bahwa anak mereka 
akan mengalami AGB. Golongan berpendapatan rendah, proporsi pengeluaran untuk pangan lebih besar dibandingkan pengeluaran lainnya, sedangkan pada golongan berpendapatan tinggi persentase pengeluaran pangan lebih kecil dibandingkan pengeluaran lainnya. Dengan demikian hal ini juga memberikan pengaruh terhadap pengaturan dan pola makan keluarga khusunya balita sehingga memiliki kaitan yang erat dengan kejadian anemia gizi besi pada balita.

2. Hubungan praktek pemberian makanan dengan kejadian anemia gizi besi pada balita di ruang anak Rumah Sakit Umum Tgk Chik Ditiro Kabupaten Pidie

Anak usia pra sekolah cenderung tumbuh lambat karena nafsu makannya menurun dan lebih senang bermain dengan teman. Oleh karena itu orang tua harus lebih telaten dalam memberikan makanan walaupun sedikit, tetapi berikan dengan frekuensi lebih sering dan anak tetap dikenalkan dengan berbagai jenis makanan. Susu harus dikurangi, cukup 2 kali dalam sehari (Supartini, 2012).

Hasil penelitian menunjukkan bahwa ibu balita dengan praktek pemberian makanan yang kurang sebagian besar memiliki balita yang mengalami AGB berat yaitu sebanyak $14(37,8 \%)$. Sedangkan ibu balita dengan praktek pemberian makanan yang baik sebagian besar memiliki balita yang mengalami AGB ringan yaitu berjumlah 12 orang (60,0\%). Berdasarkan perhitungan uji statistik dengan Chi Square diperoleh P-value 0,006 nilai tersebut lebih kecil dari $\alpha=0,05$ sehingga memperlihatkan ada hubungan antara praktek pemberian makanan dengan kejadian AGB pada balita di ruang anak Rumah Sakit Umum Tgk Chik Ditiro Kabupaten Pidie.

Hasil penelitian sejalan dengan teori yang dikemukakan oleh Sri Setyaningsih (2012) yaitu pada umumnya anemia gizi besi terjadi pada anak yang memang telah berada dalam keadaan keseimbangan besi minimal, sehinga suatu gangguan yang ringan pun dapat langsung menyebabkan keseimbangan besi yang negatif. Beberapa keadaan yang mempermudah terjadinya anemia gizi besi ialah pemberian makanan yang kurang, infeksi, infestasi parasit, keadaan sosioekonomi yang rendah dan fasilitas kesehatan yang kurang.

Menurut asumsi peneliti apabila makanan yang dikonsumsi setiap hari tidak cukup banyak mengandung zat besi atau absorpsinya rendah, maka ketersediaan zat besi untuk tubuh balita tidak akan cukup untuk memenuhi kebutuhan akan zat besi. Biasanya balita mengkonsumsi makanan yang kurang beragam, balita hanya suka terhadap makanan yang 
itu itu saja. Akan tetapi, apabila di dalam menu terdapat pula bahan-bahan makanan yang meninggikan absorpsi zat besi seperti daging, ayam, ikan, dan vitamin C, maka ketersediaan zat besi yang ada dalam makanan dapat ditingkatkan sehingga kebutuhan akan zat besi akan terpenuhi. Dengan demikian praktek pemberian makanan yang baik pada balita akan menurunkan kejadian anemia gizi besi. Oleh sebab itu, ibu ibu harus mengolah makanan secara bervariasa dan kreatif agar balita tertarik untuk mengkonsumsi makanan tersebut.

\section{KESIMPULAN}

Kesimpulan penelitian ini ada hubungan yang bermakna antara sosial ekonomi dengan nilai $\mathrm{P}=0,015$ dan ada hubungan antara praktek pemberian makanan dengan kejadian AGB pada balita di ruang anak Rumah Sakit Umum Tgk Chik Ditiro Kabupaten Pidie. Berdasarkan perhitungan uji statistik dengan Chi Square diperoleh P-value 0,002.

\section{SARAN}

Diharapkan kepada petugas kesehatan dapat meningkatkan dan mengoptimalkan kegiatan penyuluhan mengenai pencegahan anemia dan asupan gizi yang baik pada balita oleh petugas yang berhubungan langsung dengan pelayanan kesehatan anak sehingga mengurangi kejjadian anemia gizi besi pada balita dan Ibu balita lebih memperhatikan kebutuhan mikro nutrient khususnya asupan zat besi pada balita, baik dalam pengolahan makanan maupun pengaturan makanan.

\section{DAFTAR PUSTAKA}

Kemenkes RI. 2016. Profil Kesehatan Indonesia Tahun 2015. Jakarta : Kemenkes RI. . 2017. Laporan Riset Kesehatan Dasar. Jakarta: Kemenkes RI.

Kepmenkes RI. 2012. Pedoman Operasional Keluarga Sadar Gizi di Desa Siaga. Direktorat Jendral Bina Kesehatan Masyarakat. Jakarta: Kepmenkes RI.

Rahmawati. 2015. Hubungan Tingkat Pendidikan Dan Status Pekerjaan Ibu Dengan Pengetahuan Ibu Tentang Anemia Pada Anak Balita Di Kelurahan Nambangan Kidul Kecamatan Manguharjo Kota Madiun. Surakarta: Naskah Publikasi UMS

Sri Setyaningsih. 2012. Pengaruh Interaksi, Pengetahuan Dan Sikap Terhadap Praktek Ibu Dalam Pencegahan Anemia Gizi Besi Balita Di Kota Pekalongan Tahun 2012. Semarang: UNDIP.

Supartini. 2012. Buku Ajar Konsep Dasar Keperawatan Anak. Jakarta: EGC. 
Journal of Healthcare Technology and Medicine Vol. 5 No. 1 April 2019

Universitas Ubudiyah Indonesia

e-ISSN : 2615-109X

Wahyuni. 2014. Anemia Defisiensi Besi Pada Balita. Bagian Ilmu Kesehatan Masyarakat/Ilmu Kedokteran Pencegahan/Ilmu Kedokteran Komunitas Fakultas Kedokteran USU. 